\title{
Antibacterial activity of essential oils encapsulated in chitosan nanoparticles
}

\author{
Dulce Guadalupe BARRERA-RUIZ ${ }^{1}$, Geovana Carolina CUESTAS-ROSAS ${ }^{1}$, Reyna Isabel SÁNCHEZ-MARIÑEZ ${ }^{1}$, \\ Maritza Lizeth ÁLVAREZ-AINZA ${ }^{1}$, Griselda Macrina MORENO-IBARRA ${ }^{1}$, Ana Karenth LÓPEZ-MENESES ${ }^{2}$, \\ Maribel PLASCENCIA-JATOMEA ${ }^{3}$, Mario Onofre CORTEZ-ROCHA ${ }^{3 *}$
}

\begin{abstract}
In this study, cinnamon (Cinnamomum zeylanicum), thyme (Thymus vulgaris) and Schinus molle essential oils (at 125, $250 \mathrm{and} 500 \mu \mathrm{g} / \mathrm{mL}$ ) were encapsulated in chitosan nanoparticles by ionotropic gelation. Their antimicrobial activity against Staphylococcus aureus ATCC 25923, Enterococcus sp., Escherichia coli ATCC 25922, Klebsiella pneumoniae (BLEE +) and Pseudomona aeruginosa carbapenemase producer was evaluated. The obtained nanoparticles exhibited a regular distribution and spherical shape with size range of 19.7 to $361 \mathrm{~nm}$ as observed by using a laser light scattering equipment. It was found that the studied chitosan nanoparticles with essential oils showed high antimicrobial effect than the chitosan and essential oils alone. Enterococcus sp. was the most sensitive bacteria and $S$. aureus the most resistant. Chitosan nanoparticles and chitosan nanoparticles with cinnamon and thyme essential oils were capable to inhibit growth of Enterococcus sp. and K. pneumoniae. This study demonstrated that chitosan nanoparticles with essential oils were effective against some foodborne pathogens.
\end{abstract}

Keywords: viability; Schinus mole; cinnamon; thyme; essential oils.

Practical Application: Use of essential oils in encapsulated in chitosan to avoid microbial growth.

\section{Introduction}

Microbial pathogens such as Staphylococcus aureus, Escherichia coli, Pseudomonas aeruginosa and others that can be present in food may cause spoilage and contribute to foodborne disease incidence (Miladi et al., 2016). It has been reported that foodborne illness represents a serious public health threat/risk worldwide, with around 48 million people affected and 3,000 death each year only in the USA (Silva \& Domingues, 2016). One of the possible strategies to reduce foodborne infections is the development of effective preservation strategies capable of eradicating microbial contamination of foods. Interest in natural substances has focused attention on plants rich in bioactive compounds some of which are well known for their antimicrobial properties. The composition, structure as well as functional groups of their essential oils (EOs) play an important role in determining their antimicrobial activity. Plant EOs are generally recognized as safe and hence been considered as biodegradable safe natural alternative. Besides antibacterial properties of the EOs and their components, they also have been shown to exhibit antifungal and antiparasitic properties, which are possibly related to the function of these compounds in plants (Elsabee \& Abdou, 2013). The antimicrobial activity of several EOs has been attributed to the presence of phenolic compounds such as the thymol, eugenol and carvacrol in thyme, clove and oregano essential oils, respectively (Tsao \& Zhou, 2000; Lambert et al., 2001). Encapsulation is an attractive technology for protecting chemical and physical properties of essential oils to avoid unwanted changes and improving food processing. The encapsulating materials can be formed by one or more compounds such as chitosan, maltodextrin, gum arabic, hydroxypropyl methyl cellulose phthalategelatin, starch, among others, which can be used as a blend or alone (Nale et al., 2018; Prasad et al., 2018; Ahn et al., 2019; Perna et al., 2019). Chitosan has also gained interest due to its applications in food and pharmaceutics. Among others, the antimicrobial and antifungal activities of chitosan are some of its most interesting properties to improve food preservation and to reduce the use of chemical preservatives. The antimicrobial activity of chitosan has been considered in a wide variety of fungi and bacteria (Hernández-Lauzardo et al., 2008; Nazzaro et al., 2013; Feyzioglu \& Tornuk, 2016; Liu et al., 2017; Abdeltwab et al., 2019). In addition, the antibacterial activity was enhanced when chitosan was dissolved in acetic, formic or lactic acid No et al. (2002). Furthermore, Liu et al. (2006) showed that chitosan in acetic acid solutions over 200 ppm have a marked biocide response to Escherichia coli. This activity of chitosan depends on diverse factors such as the type of chitosan used, its deacetylation degree and molecular weight, the $\mathrm{pH}$ of the medium and the temperature, the target organism, etc. Chitosan has been used in combination with essential oils by using nanoencapsulation treatments that may find potential application in the food industries. Due to the fact that EOs are easy to degradation in presence of light, air and high temperatures, nanoencapsulation has been recently developed as an efficient technique to protect them from 
evaporation and oxidation (Beyki et al., 2014). It is practical approach to maintain the EOs chemical properties, therefore, the aim of this study was to determine antimicrobial activity of chitosan nanoparticles loaded with essential oils.

\section{Material and Methods}

\subsection{Bacterial strains}

Five different human pathogens were tested, two Gram positive bacteria: Staphylococcus aureus ATCC 25923 and Enterococcus sp. vancomycin resistant, as well as three Gram negative: Escherichia coli ATCC 25922, Klebsiella pneumoniae (BLEE +) and Pseudomonas aeruginosa carbapenemase producer. They were obtained from the Microbiology Laboratory, Department of the Chemical Biologist Sciences at the University of Sonora (Hermosillo, Sonora, México). Bacteria were cultured on blood agar at $37^{\circ} \mathrm{C}$ for $48 \mathrm{~h}$. All cultured were standardized by matching to the McFarland 0.5 turbidity standard using Mueller Hinton broth to produce approx. $1.5 \times 10^{8}$ colony forming units (CFU) per mL (Sánchez-García et al., 2016).

\subsection{Raw materials}

Chitosan (Cs) from shrimp shells, medium molecular weight $(153 \mathrm{kDa})$ and $78 \%$ of degree deacetylation was acquired from Sigma-Aldrich, USA (cat. 448877). Cinnamon (Cinnamomum zeylanicum, catalog w-22921-0) and thyme (Thymus capitatus, catalog w-28281-2) essential oils (CEO and TEO, respectively) were also acquired from Sigma Aldrich ${ }^{\circ}$ (St. Louis, MO, USA). In the other hand, Schinus molle leaves collected near to

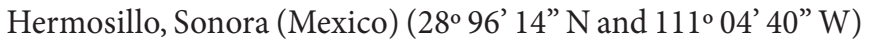
during the summer of 2019 were shade-dried for two week at $25^{\circ} \mathrm{C}$. To obtain the essential oil (EO) a sample of $100 \mathrm{~g}$ of dry leaves were hydro-distillated at $100{ }^{\circ} \mathrm{C}$ for $4 \mathrm{~h}$ in a Clevenger apparatus.

\subsection{Nanoparticles preparation}

The nanoparticles were prepared as described by López-Meneses et al. (2018). A solution of chitosan (Cs, $0.2 \% \mathrm{w} / \mathrm{v}$ ) was prepared by constant agitation during $12 \mathrm{~h}$ in an aqueous lactic acid solution $(1 \%, \mathrm{v} / \mathrm{v})$. Then, it was then centrifuged for $30 \mathrm{~min}$ at $6000 \mathrm{rpm}$ in a Hermle Labnet Z326 K centrifuge and the supernatant filtered through $1.6 \mu \mathrm{m}$ pore filter. Tween $80(0.45 \mathrm{~g})$ was added into $40 \mathrm{~mL}$ of the Cs solution and stirred at $50^{\circ} \mathrm{C}$ for $2 \mathrm{~h}$. Aliquots of $10 \mathrm{~mL}$ was added individually with $0.04 \mathrm{~g}$ of each essential oil and a fourth without EOs. After that, $3 \mathrm{~mL}$ of sodium tripolyphosphate (TPP, $0.02 \% \mathrm{w} / \mathrm{v}$ ) was dropped in a $3 \mathrm{~mL}$ aliquot of each of the samples with continuous agitation during $15 \mathrm{~min}$ to obtain the chitosan nanoparticles, S. molle, thyme, and cinnamon essential oils (NpCs, NpSEO, NpTEO, and NpCEO, respectively. Three concentration of each nanoparticles with EOs were prepared $(125,250$ and $500 \mu \mathrm{g} / \mathrm{mL})$. Finally, they were dialyzed twice with methanol $(10 \% \mathrm{w} / \mathrm{v})$ and twice with deionized water. Particle size or dispersion of size and the zeta potential of nanoparticles was carried out in triplicate using a laser light scattering (MöbiuÇ equipment Wyatt Technology, Santa Barbara, CA, USA) with a laser wavelength of $532 \mathrm{~nm}$ and scattering angle of $90^{\circ}$ (Luque-Alcaraz et al., 2016).

\subsection{Evaluation of the in vitro antimicrobial activity}

To evaluate the antibacterial activity of the nanoencapsulated EOs, the cell viability was measured according to Elshikh et al. (2016) using the resarzurin dye assay. For this, a $0.02 \mathrm{mg} / \mathrm{mL}$ solution of resazurin sodium salt powder (Sigma-Aldrich, USA cat. R7017) was prepared in distilled water, filtered through $1.2 \mu \mathrm{m}$ porous paper, sterilized and kept at $4{ }^{\circ} \mathrm{C}$. A volume of $100 \mu \mathrm{L}$ of each bacteria containing $\approx 1.5 \times 10^{8} \mathrm{CFU} / \mathrm{mL}$ in Mueller Hinton broth were deposited into each well of a flat 96-well microplate (Costar Corning, NY, USA) and incubated at $37^{\circ} \mathrm{C}$ for $4 \mathrm{~h}$. Then, $100 \mu \mathrm{L}$ of different concentration $(125,250$ and $500 \mu \mathrm{g} / \mathrm{mL})$ of each nanoparticles was added into the wells and incubated during another $14 \mathrm{~h}$. Subsequently, $20 \mu \mathrm{L}$ of resazurin sodium salt were dropped in each well and incubated for $24 \mathrm{~h}$ at $24-25^{\circ} \mathrm{C}$. The plates were read at $570 \mathrm{~nm}$ in a plate reader (Multiskan Go Thermo Scientific ${ }^{\mathrm{m}}$ ). Three controls were used: Gentamicin as positive control, treatments alone, and bacteria + Mueller Hinton broth. The experiments were carried out by triplicate. The inhibition percentage was calculated according to the equation of Lozano \& Suárez (2008):

$\%$ Inhibition $=\left[\frac{(\mathrm{ABT}-\mathrm{AM})-(\mathrm{ATB}-\mathrm{AB})}{\mathrm{ABT}-\mathrm{AB}}\right] \times 100$

Where $\mathrm{ABT}$ is the total bacteria absorbance, $\mathrm{AM}$ is the Mueller Hinton broth absorbance; ATB is the absorbance of the treatments with bacteria and $\mathrm{AB}$ is the absorbance of treatments without bacteria.

\subsection{Statistical analysis}

All experiments were performed in triplicate and data expressed as mean value \pm standard deviation. The values were subjected to a variance analysis (ANOVA). To determine the statistical difference among the mean values of treatments with $95 \%$ significance level, Tukey's multiple range test $(\mathrm{p} \leq 0.05)$ using the statistical program JMP version 5.0 was used.

\section{Results and discussion}

\subsection{Physicochemical characterization of Cs-EO's nanoparticles}

Table 1 shows the average particle size, potential zeta and the polydispersity index of the obtained nanoparticles. The $\mathrm{NpCs}$ and NpCsCEO showed irregular shape and had tendency to aggregate. The other nanoparticles showed spherical shape and according to their low polydispersity index (near to zero), they were homogeneous. The potential zeta and average size in the nanoparticles decreased when EOs were added, except for NpCsSEO, which showed an increase in the average size and

Table 1. Potential Z, average size and polydispersity index of the nanoparticles obtained.

\begin{tabular}{lccl}
\hline \multicolumn{1}{c}{ Treatment } & Potential Z $(\mathrm{Mv})$ & Diameter $(\mathrm{nm})$ & PDI \\
\hline NpCs & $+43.8 \pm 11.25$ & $361.9 \pm 31.4$ & 0.35 \\
NpCsSEO & $+40.2 \pm 7.5$ & $516.9 \pm 45.5$ & 0.74 \\
NpCsCEO & $+22.9 \pm 0.3$ & $29.3 \pm 0.9$ & 0.3 \\
NpCsTEO & $+22.7 \pm 0.8$ & $19.7 \pm 0.9$ & 0.2 \\
\hline
\end{tabular}

NpCS: chitosan nanoparticles, NpCsSEO, NpCsCEO and NpCsTEO are nanoparticles of chitosan with TEO, SEO and CEO, respectively. Values represent the mean \pm standard deviation of three replicates. 
PDI. Our results differ from those of Keawchaoon \& Yoksan (2011); Woranuch \& Yoksan (2013) and Sotelo-Boyás et al. (2017), who found an increase in the average size after loading EOs. The zeta potential of NpCs and NpCsSEO were higher than those from NpCsTEO and NpCsCEO. These high values implies a particle surface positively charged, good stability, in addition to a potential functionality. They can be considered high, which implies a particle surface positively charged, good stability, in addition to a potential functionality. The interactions between the amino groups of the chitosan and the $\mathrm{OH}$ groups of the $\mathrm{EO}$ could be responsible for the increase of this value.

\subsection{Evaluation of the in vitro antimicrobial activity}

The resarzurin reductive assay was carried out to evaluate the proliferation. This is a cell permeable redox indicator, which is used to monitor viable cell number. The viable cells with active metabolism reduce resazurin into resorufin, which is pink and fluorescent (Riss et al., 2004). The antibacterial response to EOs alone and incorporated in chitosan.

\subsection{E. coli ATCC 25922}

In the proliferation test for E. coli after $24 \mathrm{~h}$ of incubation, statistical differences were found ( $<<0.05$, Table 2$)$. E. coli was not inhibited in TEO, CEO and chitosan whereas in the other treatments its proliferation was low. The higher concentration of EOs in the nanoparticles caused moderate inhibition 10.0, 11.0, and 26.0\% (NpCsCEO, NpCsSEO, and NpCsTEO, respectively), and they were also lower than the obtained with gentamicin (39.3\%). The lower $\mathrm{CI}_{50}$ calculated was for the NpCsTEO and NpCsCEO (580 and 683, respectively), which were determined at $95 \%$ of confidence intervals using a Probit analysis

Table 2. Proliferation percentage of human pathogenic bacteria in presence of the individual essential oils $(\mu \mathrm{g} / \mathrm{mL})$ and nanoencapsulated in chitosan.

\begin{tabular}{|c|c|c|c|c|c|}
\hline Treatment & E. coli & K. pneumoniae & P. aeruginosa & Enterococcus sp. & S. aureus \\
\hline MHB & $100^{\mathrm{a}}$ & $100^{\mathrm{a}}$ & $100^{\mathrm{a}}$ & $100^{\mathrm{a}}$ & $100^{\mathrm{a}}$ \\
\hline Gentamicin & $70.3 \pm 2.1 \mathrm{~d}$ & $100^{\mathrm{a}}$ & $87.6 \pm 0.6^{\mathrm{ef}}$ & $31.9 \pm 0.5^{1}$ & $80.8 \pm 12.5^{\mathrm{fg}}$ \\
\hline \multicolumn{6}{|l|}{ Chitosan } \\
\hline 250 & $100 \pm 5.1^{\mathrm{a}}$ & $93.7 \pm 1.9^{\mathrm{bc}}$ & $100 \pm 2.9^{\mathrm{a}}$ & $98.1 \pm 2.5^{\mathrm{ab}}$ & $92.8 \pm 1.7^{\text {bcde }}$ \\
\hline 500 & $100 \pm 1.5^{\mathrm{a}}$ & $90.9 \pm 6.3^{\text {cde }}$ & $100 \pm 1.9^{\mathrm{a}}$ & $80.6 \pm 4.2^{\mathrm{ef}}$ & $91.4 \pm 0.6^{\mathrm{cde}}$ \\
\hline 250 & $100 \pm 3.0^{\mathrm{a}}$ & $58.7 \pm 5.5^{\mathrm{bcd}}$ & $100 \pm 0.7^{\mathrm{f}}$ & $75.0 \pm 4.8^{\mathrm{g}}$ & $100 \pm 1.4^{\mathrm{abcd}}$ \\
\hline 500 & $100 \pm 15.5^{\mathrm{a}}$ & $84.8 \pm 2.8^{\mathrm{def}}$ & $100 \pm 2.2^{\mathrm{h}}$ & $46.7 \pm 3.0^{\text {ef }}$ & $94.2 \pm 1.7^{\mathrm{abcd}}$ \\
\hline \multicolumn{6}{|l|}{ CEO } \\
\hline 125 & $100 \pm 0.0^{\mathrm{a}}$ & $98.2 \pm 5.3^{\mathrm{abc}}$ & $99.4 \pm 5.9^{\mathrm{ab}}$ & $94.5 \pm 3.4^{\mathrm{abc}}$ & $100 \pm 0.9^{\mathrm{a}}$ \\
\hline 250 & $100 \pm 5.5^{\mathrm{a}}$ & $81.0 \pm 6.3^{\mathrm{g}}$ & $100 \pm 0.7^{\mathrm{a}}$ & $75.8 \pm 1.2^{\mathrm{fg}}$ & $100 \pm 1.6^{\mathrm{a}}$ \\
\hline 500 & $82.4 \pm 6.3^{\mathrm{bc}}$ & $86.7 \pm 4.3^{\mathrm{fg}}$ & $62.8 \pm 1.0^{\mathrm{h}}$ & $81.3 \pm 3.1^{\mathrm{jk}}$ & $96.6 \pm 5.3^{\mathrm{abcd}}$ \\
\hline \multicolumn{6}{|l|}{$\mathrm{NpCs}$} \\
\hline 125 & $95.7 \pm 1.3^{\mathrm{a}}$ & $47.6 \pm 5.3^{1}$ & $88.5 \pm 0.6^{\mathrm{def}}$ & $78.7 \pm 4.8^{\mathrm{efg}}$ & $75.4 \pm 3.0^{\mathrm{g}}$ \\
\hline 250 & $95.5 \pm 2.2^{\mathrm{a}}$ & $30.0 \pm 2.8^{\mathrm{m}}$ & $67.6 \pm 4.2^{\mathrm{h}}$ & $57.0 \pm 1.5^{\mathrm{hi}}$ & $76.5 \pm 5.4^{\mathrm{g}}$ \\
\hline 500 & $76.8 \pm 5.3^{b}$ & $15.9 \pm 4.3^{\mathrm{n}}$ & $65.4 \pm 0.2^{\mathrm{h}}$ & $6.1 \pm 3.1^{\mathrm{n}}$ & $66.6 \pm 1.7^{\mathrm{h}}$ \\
\hline \multicolumn{6}{|l|}{ NpCsSEO } \\
\hline 125 & $99.2 \pm 1.4^{\mathrm{a}}$ & $86.0 \pm 7.0^{\mathrm{efg}}$ & $95.4 \pm 3.5^{\mathrm{abc}}$ & $83.4 \pm 3.4^{\mathrm{de}}$ & $87.0 \pm 5.5^{\mathrm{ef}}$ \\
\hline 250 & $87.4 \pm 0 . b^{2}$ & $56.9 \pm 4.6^{\mathrm{kl}}$ & $93.3 \pm 3.3^{\mathrm{bcd}}$ & $62.8 \pm 9.7^{\mathrm{h}}$ & $63.3 \pm 4.9^{\mathrm{h}}$ \\
\hline 500 & $75.9 \pm 6.3^{\mathrm{cd}}$ & $49.2 \pm 5.5^{\mathrm{kl}}$ & $75.1 \pm 3.4^{\mathrm{g}}$ & $29.6 \pm 8.5^{1}$ & $67.5 \pm 3.3^{\mathrm{h}}$ \\
\hline \multicolumn{6}{|l|}{ NpCsCEO } \\
\hline
\end{tabular}

$\mathrm{MHB}=$ Mueller Hinton Broth, $\mathrm{SEO}=$ S. molle, TEO = thyme and CEO = Cinnamon essential oils. NpCs: chitosan nanoparticles, NpCsSEO, NpCsCEO and NpCsTEO are nanoparticles of chitosan with TEO, SEO and CEO, respectively. Values represent the mean \pm standard deviation of three replicates. Same lowercase letter in the superscript indicate no statistical difference $(\mathrm{P}<0.05)$ among treatments for each bacteria. 
with NCSS 97 statistical program (NCSS, LLC., Kaysville, UT, USA). This agrees to Chen et al. (2009) findings, because they reported that NpCs grafted with two essential oils components, eugenol or carvacrol, had more antibacterial activity than NpCs against E. coli. In addition, they mentioned that modification of chitosan nanoparticles with the essential oil components via the Schiff base reaction involved the amine group of chitosan, and it might be expected that the antibacterial properties of the chitosan will be compromised such as occurred in our study.

A study of Saei-Dehkordi et al. (2010) and Tiwari et al. (2009) reported that among the organisms they evaluated, the Gram negative bacteria were the most resistant and the Gram positive were the most susceptible ones. This does not match totally with our finding, just for E. coli and Enterococcus sp. It has been reported previously (Sandri et al., 2007) that the resistance of the Gram negative bacteria could be due to the presence of their impermeable outer membrane that provide hydrophilic properties to lipophilic compounds such as the essential oils. In the other hand, the no existence of this barrier in the Gram-positive bacteria favors the contact of the essential oil with the phospholipid bilayer of the cell membrane. Thus might cause an increase in the ion permeability and leakage of intracellular constituents or an impairment of the bacteria enzyme systems (Yi et al., 2014; Nakayama et al., 2013). In addition, the inhibitory effect of phenols could be explained by interactions with the cell membrane of microorganisms and is often correlated with the hydrophobicity of the compounds (Sikkema et al., 1995; Weber \& de Bont, 1996). For instance, Lambert et al. (2001) found that oregano essential oil induces permeability alteration in $P$. aeruginosa and S. aureus membranes with a consequent leakage of protons, phosphates and potassium.

\subsection{S. aureus ATCC 25923}

From the response of $S$. aureus to the treatments it was found that, there is significant difference among them $(\mathrm{p}<0.05)$. The NpCs $(500 \mu \mathrm{g} / \mathrm{mL})$ and NpCsSEO $(250$ and $500 \mu \mathrm{g} / \mathrm{mL})$ reduced the proliferation by $35.0 \%$ while gentamicin only caused $19.2 \%$, which indicate that nanoparticles were more effective (Table 2). In addition, our data showed that CEO did not produced any effect in this bacteria, along with TEO $(125$ and $250 \mu \mathrm{g} / \mathrm{mL})$ and SEO $(125 \mu \mathrm{g} / \mathrm{mL})$. All the $\mathrm{CI}_{50}$ were higher than the obtained with the NpCsSEO $(1017 \mu \mathrm{g} / \mathrm{mL})$. However, according to a study by Keawchaoon \& Yoksan (2011), chitosan nanoparticles with carvacrol exhibited antimicrobial activity against $S$. aureus, B. cereus, and E. coli compared to chitosan nanoparticles. They also demonstrated that this activity was more effective against Gram positive bacteria which does not match with our results. Thymol, carvacrol, linalool and $\gamma$-terpinene are the main components of thyme essential oil (Akrout et al., 2010) and they have shown antimicrobial activity. Those compounds are terpenoids and their antimicrobial activity is related to their functional groups, and the hydroxyl groups on the phenolic terpenoids along with the presence of delocalized electrons (Ben Arfa et al., 2006; Lambert et al., 2001). In addition, Ben Arfa et al. (2006) mentioned that thymol and carvracol are capable to disintegrating the cell outer membrane.

\subsection{Enterococcus sp. (vancomicin resistant)}

The antimicrobial activity of the treatments against Enterococcus sp. is shown in Table 2. It can be seen that they showed inhibitory effect on the proliferation of this microorganism. We found that it was the most sensitive bacteria from all the above tested. The highest antiproliferative activity was obtained with the nanoparticles at $500 \mu \mathrm{g} / \mathrm{mL}(\mathrm{NpCs}>\mathrm{NpCsCEO}>\mathrm{NpCsTEO}$ and NpCsSEO, 6.1, 13.0, 29, 30\%, respectively) compared to gentamicin $(31.9 \%)$ and the EOs alone except for CEO at $500 \mu \mathrm{g} / \mathrm{mL}$ which activity was closer to the gentamicin. The $\mathrm{CI}_{50}$ for SEO, CEO, TEO, NpCs, NpCsTEO and NpCsCEO were $414,472,233,317,195$ and $193 \mu \mathrm{g} / \mathrm{mL}$, respectively. The synergy among chitosan and the components of each $\mathrm{EO}$ can be easily observed. Unlu et al. (2010) and Ribeiro-Santos et al. (2017) stated that cinnamaldehyde is the major compound in cinnamon $\mathrm{EO}$ which has proven to be effective against some species of both Gram positive and negative bacteria (Friedman et al., 2002; Ooi et al., 2006). Ribeiro-Santos et al. (2017) found that Cinnamomum cassia $\mathrm{EO}$ exhibited great antimicrobial activity against E. coli, S. aureus and other microorganisms. Furthermore, cinnamaldehyde and eugenol caused damage to the cell wall of the bacteria (Di Pasqua et al., 2007) and cinnamaldehyde reduces the activity of enzymes causing protein denaturation and increases the cell wall permeability, thereby permitting leakage of cell components resulting in cell death (Tiwari et al., 2009).

\subsection{K. pneumoniae BLEE}

As shown in Table 2, gentamicin and chitosan $(125 \mu \mathrm{g} / \mathrm{mL})$ did not show antiproliferative activity. This could be due to its resistance to extended spectrum $\beta$-lactamases antibiotics that K pneumoniae possesses. Kader \& Kumar (2005) found isolates of Klebsiella highly resistant to gentamicin that agrees to our results. Also, Díaz et al. (2004) reported that 65 of 100 strains isolated from several hospitals of different Chilean cities resulted gentamicin resistant. A dose-response was observed in most of the treatments. The highest antiproliferative activity was observed with the NpCs followed by the NpCsCEO and NpCsSEO which inhibition ranged from 50 to $84.8 \%$. The lower $\mathrm{CI}_{50}$ were for the NpCs, NpCsCEO, NpCsSEO and NpCsTEO $(115,161,422$ and $610 \mu \mathrm{g} / \mathrm{mL}$, respectively).

\subsection{P. aeruginosa carbapenemase producer}

As can be seen in Table 2 for $P$. aeruginosa the treatments of SEO, TEO, NpCs, and NpCsSEO at 250 and $500 \mu \mathrm{g} / \mathrm{mL}$ were statistically significant $(\mathrm{p}<0.05)$. Proliferation of this bacteria was high in most of the treatments and to gentamicin. Thyme and $S$. molle EOs produced similar inhibition in the proliferation followed by NpCs. Martins et al. (2014) and López-Meneses et al. (2018) reported that the main components in the leaves of S. molle $\mathrm{EO}$ are D-limonene, o-cimene, $\beta$-phellandrene, $\delta$-cadinene and caryophillene. Martins et al. (2014) found that leaf EO was effective against Staphylococcus epidermidis, S. aureus, Enterococcus faecalis while fruit EO was more effective against S. aureus and E. faecalis. Also, both EOs were effective against antibiotic-resistant Gram bacteria, P. aeruginosa and Salmonella entiritidis serovar Typhimurium. Also, Mendonça-Rocha et al. (2012), demonstrated that $\mathrm{EO}$ of $S$. molle has high inhibitory effect 
against S. aureus ATCC 25923 strain, for E. coli ATCC 25922 the inhibitory effect was smaller, however, it was strong when the undiluted crude extract $(950 \mathrm{mg} / \mathrm{mL})$ was applied. Also, they found that $P$. aeruginosa ATCC 27853 strain was less sensitive for this oil. These results agrees to our findings. The lowest $\mathrm{CI}_{50}$ was for Cs, CEO and NpCsCEO (24, 33 and $690 \mu \mathrm{g} / \mathrm{mL}$, respectively).

\section{Conclusions}

In general terms, the chitosan nanoparticles with EOs of cinnamon, thyme and $S$. molle showed the highest antimicrobial effect than the chitosan and EOs alone. Even that chitosan have been reported to exhibit high bactericidal effects against Gram positive, there were no marked trends in inhibitory effects of NpCsEOs against both types of bacteria. Enterococcus sp. was the most sensitive bacteria and $S$. aureus the most resistant. NpCS, NpCsCE and NpCsTEO were capable to inhibit growth of Enterococcus sp. and K. pneumoniae. This study demonstrated that chitosan nanoparticles with essential oils were effective against some foodborne pathogens and seems to have a beneficial impact on microbial reduction. These finding implied that NpCsEOs could be used as an antimicrobial agent in the food industry.

\section{Acknowledgements}

This work was supported by the project US0313006033 funded by the División de Ciencias Biológicas y de la Salud de la Universidad de Sonora.

\section{References}

Abdeltwab, W. M., Abdelaliem, Y. F., Metry, W. A., \& Eldeghedy, M. (2019). Antimicrobial effect of chitosan and nano-chitosan against some pathogens and spoilage microorganisms. Journal of Advanced Laboratory Research in Biology, 10(1), 8-15.

Ahn, S. I., Kim, A. Y., \& Kwak, H. S. (2019). Optimization of the microencapsulation conditions and physicochemical properties of enteric-coated lactase microcapsules. International Journal of Dairy Technology, 72(1), 23-35. http://dx.doi.org/10.1111/1471-0307.12556.

Akrout, A., El Jani, H., Amouri, S., \& Neffati, M. (2010). Screening of antiradical and antibacterial activities of essential oils of Artemisia campestris L., Artemisia herba alba Asso, and Thymus capitatus Hoff. et Link. growing wild in the Southern of Tunisia. Recent Research in Science and Technology, 2(1), 29-39.

Ben Arfa, A., Combes, S., Preziosi-Belloy, L., Gontard, N., \& Chalier, P. (2006). Antimicrobial activity of carvacrol related to its chemical structure. Letters in Applied Microbiology, 43(2), 149-154. http:// dx.doi.org/10.1111/j.1472-765X.2006.01938.x. PMid:16869897.

Beyki, M., Zhaveh, S., Tahere Khalili, S., Rahmani-Cherati, T., Abollahi, A., Bayat, M., Tabatabaei, M., \& Mohsenifar, A. (2014). Encapsulation of Mentha piperita essential oils in chitosan-cinnamic acid nanogel with enhanced antimicrobial activity against Aspergillus flavus. Industrial Crops and Products, 54, 310-319. http://dx.doi.org/10.1016/j. indcrop.2014.01.033.

Chen, F., Shi, Z., Neoh, K. G., \& Kang, E. T. (2009). Antioxidant and antibacterial activities of eugenol and carvacrol-grafted chitosan nanoparticles. Biotechnology and Bioengineering, 104(1), 30-39. http://dx.doi.org/10.1002/bit.22363. PMid:19408318.

Di Pasqua, R., Betts, G., Hoskins, N., Edwards, M., Ercolini, D., \& Mauriello, G. (2007). Membrane toxicity of antimicrobial compounds from essential oils. Journal of Agricultural and Food Chemistry, 55(12), 4863-4870. http://dx.doi.org/10.1021/jf0636465. PMid:17497876.

Díaz, P., Bello, H., Domínguez, M., Trabal, N., Mella, S., Zemelman, R., \& González, G. (2004). Resistencia a gentamicina, amikacina y ciprofloxacina en cepas hospitalarias de Klebsiella pneumoniae subespecie pneumoniae productoras de $ß$-lactamasas de espectro extendido. Revista Medica de Chile, 132(10), 1173-1178. http:// dx.doi.org/10.4067/S0034-98872004001000003. PMid:15631204.

Elsabee, M. Z., \& Abdou, E. S. (2013). Chitosan based edible films and coatings: A review. Materials Science and Engineering C, 33(4), 18191841. http://dx.doi.org/10.1016/j.msec.2013.01.010. PMid:23498203.

Elshikh, M., Ahmed, S., Funston, S., Dunlop, P., McGaw, M., Marchant, R., \& Banat, I. M. (2016). Resazurin-based 96-well plate microdilution method for the determination of minimum inhibitory concentration of biosurfactants. Biotechnology Letters, 38(6), 1015-1019. http:// dx.doi.org/10.1007/s10529-016-2079-2. PMid:26969604.

Feyzioglu, G. C., \& Tornuk, F. (2016). Development of chitosan nanoparticles loaded with summer savory (satureja hortensis L.) essential oil for antimicrobial and antioxidant delivery applications. Lebensmittel-Wissenschaft + Technologie, 70, 104-110. http://dx.doi. org/10.1016/j.lwt.2016.02.037.

Friedman, M., Henika, P. R., \& Mandrell, R. E. (2002). Bactericidal activities of plant essential oils and some of their isolated constituents against Campylobacter jejuni, Escherichia coli, Listeria monocytogenes and Salmonella enterica. Journal of Food Protection, 65(10), 1545-1560. http://dx.doi.org/10.4315/0362-028X-65.10.1545. PMid:12380738.

Hernández-Lauzardo, A. N., Bautista-Baños, S., Velázquez-del Valle, M. G., Méndez-Montealvo, M. G., Sánchez-Rivera, M. M., \& BelloPérez, L. A. (2008). Antifungal effects of chitosan with different molecular weights on in vitro development of Rhizopus stolonifer (Ehrenb.: Fr.) Vuill. Carbohydrate Polymers, 73(4), 541-547. http:// dx.doi.org/10.1016/j.carbpol.2007.12.020. PMid:26048219.

Kader, A. A., \& Kumar, A. (2005). Prevalence and antimicrobial susceptibility of extended-spectrum $\beta$-lactamase-producing Escherichia coli and Klebsiella pneumoniae in a general hospital. Annals of Saudi Medicine, 25(3), 239-242. http://dx.doi.org/10.5144/02564947.2005.239. PMid:16119526.

Keawchaoon, L., \& Yoksan, R. (2011). Preparation, characterization and in vitro release study of carvacrol-loaded chitosan nanoparticles. Colloids and Surfaces. B, Biointerfaces, 84(1), 163-171. http://dx.doi. org/10.1016/j.colsurfb.2010.12.031. PMid:21296562.

Lambert, R. J., Skandamis, P. N., Coote, P. J., \& Nychas, G. J. (2001). A study of minimum inhibitory concentration and mode of action of oregano essential oil, thymol and carvacrol. Journal of Applied Microbiology, 91(3), 453-462. http://dx.doi.org/10.1046/j.13652672.2001.01428.x. PMid:11556910.

Liu, N., Chen, X. G., Park, H. J., Liu, C. G., Liu, C. S., Meng, X. H., \& Yu, L. J. (2006). Effect of MW and concentration of chitosan on antibacterial activity of Escherichia coli. Carbohydrate Polymers, 64(1), 60-65. http://dx.doi.org/10.1016/j.carbpol.2005.10.028.

Liu, Q., Meng, X., Li, Y., Zhao, C. N., Tang, G. Y., \& Li, H. B. (2017). Antibacterial and antifungal activities of spices. International Journal of Molecular Sciences, 18(6), 283. http://dx.doi.org/10.3390/ ijms18061283. PMid:28621716.

López-Meneses, A. K., Plascencia-Jatomea, M., Lizardi-Mendoza, J., Fernández-Quiroz, D., Rodríguez-Félix, F., Mouriño-Pérez, R. R., \& Cortez-Rocha, M. O. (2018). Schinus molle L. essential oil-loaded chitosan nanoparticles: Preparation, characterization, antifungal and anti-aflatoxigenic properties. Lebensmittel-Wissenschaft + Technologie, 96, 597-603. http://dx.doi.org/10.1016/j.lwt.2018.06.013. 
Lozano, J. M., \& Suárez, L. E. C. (2008). Propiedades antimicrobianas in vitro de metabolitos secundarios aislados de Peltostigma guatemalense, una especie colombiana de Rutaceas contra el parásito Plasmodium falciparum y contra cepas bacterianas. Revista Colombiana de Ciencias Químico-Farmacéuticas, 37(2):164-176.

Luque-Alcaraz, A. G., Cortez-Rocha, M. O., Velázquez-Contreras, C. A., Acosta-Silva, A. L., Santacruz-Ortega, H. D. C., Burgos-Hernández, A., \& Plascencia-Jatomea, M. (2016). Enhanced antifungal effect of chitosan/pepper tree (Schinus molle) essential oil bionanocomposites on the viability of Aspergillus parasiticus spores. Journal of Nanomaterials, 38, 1-10. http://dx.doi.org/10.1155/2016/6060137.

Martins, M. R., Arantes, S., Candeias, F., Tinoco, M. T., \& Cruz-Morais, J. (2014). Antioxidant, antimicrobial and toxicological properties of Schinus molle L. essential oils. Journal of Ethnopharmacology, 151(1), 485-492. http://dx.doi.org/10.1016/j.jep.2013.10.063. PMid:24231069.

Mendonça-Rocha, P., Rodilla, J., Díez, D., Elder, H., Guala, M., Silva, L., \& Pombo, E. (2012). Synergistic antibacterial activity of the essential oil of aguaribay (Schinus molle L.). Molecules (Basel, Switzerland), 17(10), 12023-12036. http://dx.doi.org/10.3390/molecules171012023. PMid:23085653.

Miladi, H., Zmantar, T., Chaabouni, Y., Fedhila, K., Bakhrouf, A., Mandouani, K., \& Chaieb, K. (2016). Antibacterial and efflux pump inhibitors of thymol and carvacrol against food-borne pathogens. Microbial Pathogenesis, 99, 95-100. http://dx.doi.org/10.1016/j. micpath.2016.08.008

Nakayama, M., Shimatani, K., Ozawa, T., Shigemune, N., Tsugukuni, T., Tomiyama, D., \& Miyamoto, T. (2013). A study of the antibacterial mechanism of catechins: Isolation and identification of Escherichia coli cell surface proteins that interact with epigallocatechin gallate. Food Control, 33(2), 433-439. http://dx.doi.org/10.1016/j. foodcont.2013.03.016.

Nale, Z., Tontul, I., Arslan, A. A., \& Nadeem, H. S. (2018). Microbial ability, physicochemical and sensory properties of kefir microcapsules prepared using maltodextrin/Arabic gum mixes. International Journal of Dairy Technology, 71(S1), 61-72. http://dx.doi.org/10.1111/14710307.12402 .

Nazzaro, F., Fratianni, F., Martino, L., Coppola, R., \& de Feo, V. (2013). Effect of essential oils on pathogenic bacteria. Pharmaceuticals., 6(12), 1451-1471. http://dx.doi.org/10.3390/ph6121451. PMid:24287491.

No, H. K., Park, N. Y., Lee, S. H., \& Meyers, S. P. (2002). Antibacterial activity of chitosans and chitosan oligomers with different molecular weights. International Journal of Food Microbiology, 74(1-2), 65-72. http://dx.doi.org/10.1016/S0168-1605(01)00717-6. PMid:11929171.

Ooi, L. S. M., Li, Y. L., Kam, S. L., Wang, H., Wong, E. Y. L., \& Ooi, V. E. C. (2006). Antimicrobial activities of cinnamon oil and cinnamaldehyde from the Chinese medicinal herb Cinnamomum cassia Blume. The American Journal of Chinese Medicine, 34(3), 51-522. http://dx.doi. org/10.1142/S0192415X06004041. PMid:16710900.

Perna, A. M., Simonetti, A., \& Gambacorta, E. (2019). Phenolic content and antioxidant activity of donkey milk kefir fortified with sulla honey and rosemary essential oil during refrigerated storage. International Journal of Dairy Technology, 72(1), 74-81. http://dx.doi. org/10.1111/1471-0307.12561.

Prasad, W., Kaushik, K., Mandal, S., \& Badola, R. (2018). Effect of combination of essential oils on physicochemical and sensorial attributes of burfi in comparison with individual essential oils and BHA. International Journal of Dairy Technology, 71(3), 810-819. http://dx.doi.org/10.1111/1471-0307.12512.

Ribeiro-Santos, R., Andrade, M., \& Sanches-Silva, A. (2017). Application of encapsulated essential oils as antimicrobial agents in food packaging. Current Opinion in Food Science, 14, 78-84. http://dx.doi. org/10.1016/j.cofs.2017.01.012.

Riss, T. L., Moravec, R. A., Niles, A. L., Benink, H. A., Worzella, T. J., \& Minor, L. (2004). Assay guidance manual: cell viability assays (pp. 11-12). Bethesda: Eli Lilly \& Company and the National Center for Advancing Translational Sciences.

Saei-Dehkordi, S. S., Tajik, H., Moradi, M., \& Khalighi-Sigaroodi, F. (2010). Chemical composition of essential oils in Zataria multiflora Boiss. From different parts of Iran and their radical scavenging and antimicrobial activity. Food and Chemical Toxicology, 48(6), 15621567. http://dx.doi.org/10.1016/j.fct.2010.03.025. PMid:20332011.

Sánchez-García, E., Castillo-Hernández, S. L., \& García-Palencia, P. (2016). Actividad antimicrobiana. In: C. Rivas-Morales, M. A. Oranday-Cardenas \& M. J. Verde-Star (Eds.), Investigación en plantas de importancia médica (pp. 77-100). OmniaScience: Barcelona, España. http://dx.doi.org/10.3926/oms.334.

Sandri, I. G., Zacaria, J., Fracaro, F., Delamare, A. P. L., \& Echeverrigaray, S. (2007). Antimicrobial activity of the essential oils of Brazilian species of the genus Cunila against foodborne pathogens and spoiling bacteria. Food Chemistry, 103(3), 823-828. http://dx.doi. org/10.1016/j.foodchem.2006.09.032.

Sikkema, J., De Bont, J., \& Poolman, B. (1995). Mechanisms of membrane toxicity of hydrocarbons. Microbiological Reviews, 59(2), 201-222. http://dx.doi.org/10.1128/MMBR.59.2.201-222.1995. PMid:7603409.

Silva, F., \& Domingues, F. C. (2016). Antimicrobial activity of coriander oil and its effectiveness as food preservative. Critical Reviews in Food Science and Nutrition, 57(1), 35-47. http://dx.doi.org/10.1080/1040 8398.2013.847818. PMid:25831119.

Sotelo-Boyás, M., Correa-Pacheco, Z., Bautista-Baños, S., \& Gómez Y Gómez, Y. (2017). Release study and inhibitory activity of thyme essential oil-loaded chitosan nanoparticles and nanocapsules against foodborne bacteria. International Journal of Biological Macromolecules, 103, 409-414. http://dx.doi.org/10.1016/j.ijbiomac.2017.05.063. PMid:28526346.

Tiwari, B. K., Valdramidis, V. P., O’Donnell, C. P., Muthukumarappan, K., Bourke, P., \& Cullen, P. J. (2009). Application of natural antimicrobials for food preservation. Journal of Agricultural and Food Chemistry, 57(14), 5987-6000. http://dx.doi.org/10.1021/ jf900668n. PMid:19548681.

Tsao, R., \& Zhou, T. (2000). Antifungal activity of monoterpenoids against postharvest pathogens Botrytis cinerea and Monilinia fructicola. The Journal of Essential Oil Research, 12(1), 113-121. http://dx.doi.org/ 10.1080/10412905.2000.9712057.

Unlu, M., Ergene, E., Unlu, G. V., Zeytinoglu, H. S., \& Vural, N. (2010). Composition, antimicrobial activity and in vitro cytotoxicity of essential oil from Cinnamomum zeylanicum Blume (Lauraceae). Food and Chemical Toxicology, 48(11), 3274-3280. http://dx.doi. org/10.1016/j.fct.2010.09.001. PMid:20828600.

Weber, F. J., \& de Bont, J. A. M. (1996). Adaptation mechanisms of microorganisms to the toxic effects of organic solvents on membranes. Biochimica et Biophysica Acta, 1286(3), 225-245. http://dx.doi. org/10.1016/S0304-4157(96)00010-X. PMid:8982284.

Woranuch, S., \& Yoksan, R. (2013). Eugenol-loaded chitosan nanoparticles: I. Thermal stability improvement of eugenol through encapsulation. Carbohydrate Polymers, 96(2), 578-585. http://dx.doi.org/10.1016/j. carbpol.2012.08.117. PMid:23768603.

Yi, S., Wang, W., Bai, F., Zhu, J., Li, J., Li, X., Xu, Y., Sun, T., \& He, Y. (2014). Antimicrobial effect and membrane active mechanism of tea polyphenols against Serratia marcescens. World Journal of Microbiology \& Biotechnology, 30(2), 451-460. http://dx.doi.org/10.1007/s11274013-1464-4. PMid:23979827. 